\title{
Use of benchmarking to monitor and analyze effects of herd size and herd milk yield on cattle health and welfare in Austrian dairy farms
}

\author{
C. Egger-Danner, ${ }^{1 *} \odot$ A. Köck, ${ }^{1} \odot$ K. Fuchs, ${ }^{2}$ B. Grassauer, ${ }^{3}$ B. Fuerst-Waltl, ${ }^{4} \odot$ and W. Obritzhauser ${ }^{5,6} \odot$ \\ ${ }^{1}$ ZuchtData EDV-Dienstleistungen $\mathrm{GmbH}, 1200$ Vienna, Austria \\ 2Data, Statistics and Risk Assessment, Austrian Agency for Health and Food Safety (AGES), 8010 Graz, Austria \\ ${ }^{3}$ Veterinary Practice, 8853 Ranten, Austria \\ ${ }^{4}$ Department of Sustainable Agricultural Systems, Division of Livestock Sciences, University of Natural Resources and Life Sciences (BOKU), \\ Vienna, 1180 Vienna, Austria \\ ${ }^{5}$ Institute of Veterinary Public Health, University of Veterinary Medicine, 1210 Vienna, Austria \\ ${ }^{6}$ Veterinary Practice, 8605 Parschlug, Austria
}

\begin{abstract}
The modernization and intensification of the dairy industry has led to larger herd sizes and higher milk production, both globally and in Austria. Benchmarking allows the monitoring of animal health and welfare as well as the identification of potential for improvement by comparing certain parameters with other farms with similar management environments. Using data from the Austrian routine recording system of various traits of milk production, fertility, and health, farmers and their veterinarians (with the consent of the farmer) can compare farm parameters with detailed data available from their district or state and ensure more efficient herd management. The aim of the present study was to provide an overview of dairy milk production in Austria based on the annual herd health reports and to examine the effects of herd size and milk production on fertility and health parameters. Annual herd health reports from all farms participating in the health monitoring system were considered, and analyses were conducted across breeds. A large variation between farms was observed. The results showed that, based on parameters of milk yield and herd size for the range of farms within this study, it cannot be concluded that these circumstances automatically lead to poor animal health. Farms with very small herd sizes differed significantly from those with larger herd sizes. Overall herd size effects were however small in Austria. Higher milk production based on a single farm does not necessarily cause more health and fertility problems; however, we detected a tendency for an increased risk
\end{abstract}

Received April 4, 2019.

Accepted March 24, 2020.

*Corresponding author: egger-danner@zuchtdata.at of fertility, udder, and metabolic diagnoses. An active health management program might result in higher incidence rates for fertility or udder diagnoses, as a veterinary treatment might be economically superior if, for example, the calving interval can be shortened or the somatic cell count can be reduced. The results of the present study showed that it is advisable to use different benchmarks in combination for monitoring health, as well as for deciding on strategies to improve overall herd health management. Animal health reports on Austrian dairy cows are continuously being developed and new parameters integrated.

Key words: benchmarking, fertility, health monitoring, dairy farm

\section{INTRODUCTION}

The modernization and intensification of dairy farms has led to larger herd sizes and higher milk production, both globally and in Austria (Barkema et al., 2015; ZAR, 2018). Farms with tens of thousands of cows exist in the United States, Saudi Arabia, and China (Hultgren, 2017). In contrast, the average herd size in Austria is 18 dairy cows (ZAR, 2018), which is much lower than in other European countries (e.g., France: 57; Germany: 61; the Netherlands: 101; Denmark: 190; ICAR, 2018). However, the number of Austrian farms with more than 50 cows increased 10-fold from 137 farms in the year 2000 to 1,366 in 2017 . These larger farms produced $700,000 \mathrm{t}$ of milk, one-quarter of the total national milk production. In addition, the average milk yield per cow in Austria increased from 5,873 kg in 2000 to $7,434 \mathrm{~kg}$ in 2017 (ZAR, 2018). This increase is due to improved genetic selection, combined with adapted nutrition and management practices.

At the same time, animal welfare is increasing in importance and relevance to consumers. A common public perception is that animals raised on larger farms 
have poorer welfare than those on smaller farms (Lassen et al., 2006; Krystallis et al., 2009; Tonsor et al., 2009). A survey conducted in the United States found that most $(57 \%)$ agreed or strongly agreed with the statement, "farm animals raised on small farms have a better life than those raised on large farms" (Lusk et al., 2007). According to Colditz et al. (2014), methods for regular assessment of the level of animal welfare in dairy herds are needed (1) to determine compliance with policy, law, and regulatory standards; (2) to assure both consumers and non-consumers that certain aspects of the welfare of animals are being met; and (3) to assist farmers in monitoring and improving the welfare of their herds.

A promising approach for monitoring and improving animal welfare in dairy herds is the use of benchmarking (von Keyserlingk et al., 2012, 2013). Benchmarking allows dairy producers to assess their current performance relative to others and identify potential for improvement (von Keyserlingk et al., 2012).

In recent years, several animal health benchmarks have been defined based on data from the Austrian routine recording system (Egger-Danner et al., 2012). The data available provide a comprehensive overview of dairy farms in Austria. Diagnostic data, as well as already-existing information from performance recording, can be used for management decisions to improve health status in cattle herds. All of these data are stored in the central cattle database, Rinderdatenverbund (RDV, https://www.rdv-gmbh.net/).
In Austria in 2017, there were 30,272 dairy farms with 543,421 dairy cows. Of these, $66 \%$ of dairy herds and $80 \%$ of dairy cows were enrolled in the milk recording system (ZAR, 2018). Test-day records are taken at 5 -wk intervals, following an alternate a.m.-p.m. recording scheme. Artificial insemination and calving data are recorded routinely on all farms under milk recording (ZAR, 2018). A nationwide health-monitoring system for cattle was established in Austria in 2006 and has since become a routine part of performance recording (Egger-Danner et al., 2012). Veterinary diagnoses subject to documentation by law are standardized, validated, and recorded in the central cattle database. Diagnostic data are standardized using a coding system consisting of 65 diagnoses divided into the following categories: udder diseases, fertility disorders, metablic diseases, foot and leg disorders, digestive disorders, calf-specific diseases (e.g., navel ill), respiratory diseases, cardiovascular disorders, skin disorders, central nervous system disease, and infections. The documented diagnoses are sent electronically to the central cattle database by the veterinarians or are registered by the milk performance recording technicians (Figure 1). Currently $62 \%$ of all Austrian dairy herds and $71 \%$ of dairy cows are enrolled in the health monitoring system (ZAR, 2018).

The objectives of this paper were to describe fertility, udder health, and metabolic health parameters on Austrian dairy farms and to compare the variation of these figures between farms. In addition, the effects of

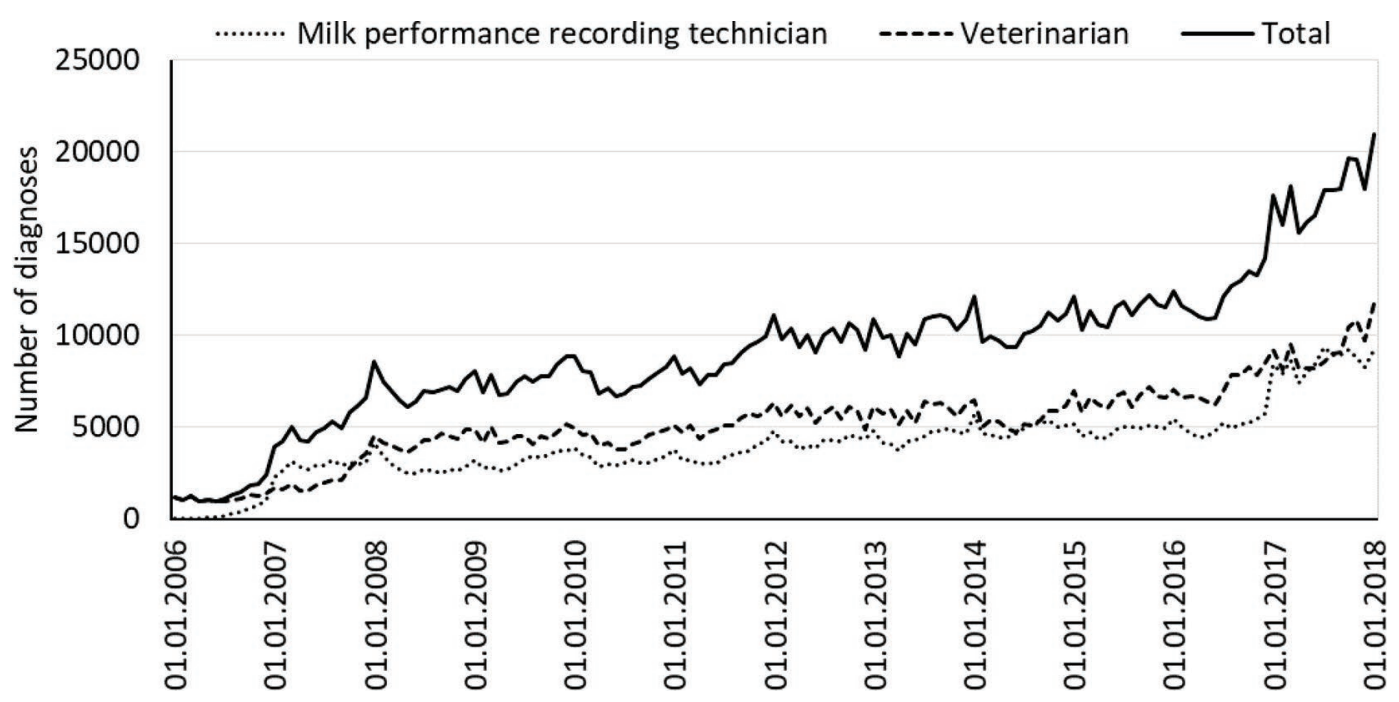

Figure 1. Number of diagnoses recorded in the central cattle database from January 1, 2006, to January 1, 2018, per month by milk reporting performance technician and veterinarians, as well as total diagnoses reported. 
herd size and of milk production on fertility and health were analyzed.

\section{MATERIALS AND METHODS}

\section{Data}

Annual Herd Health Reports. Annual herd health reports from 2008 to 2017 were provided by ZuchtData (Vienna, Austria). Since January 2008, annual herd health reports have been available for farmers participating in the Austrian health monitoring system. Annual herd health reports, covering the recording period from October 1 of the previous year to September 30 (each report covers exactly $12 \mathrm{mo}$ ), provide the basis for evaluating the general health situation of the herd. The information obtained can be used for management decisions to improve the overall health status of the cattle herd. All of these annual herd health data are accessible to the farmer via the online herd management program and application LKV-Herdenmanager (https://zar.at/Service/ RDV-Portal/LKV-Herdenmanager.html). Various graphs enable a rapid overview of the farmer's own herd compared with means for the district and federal state. Benchmarks can be analyzed over time and improvements or setbacks visualized. Through continuous monitoring, issues can be detected and neutralized at an early stage. In accordance with data protection agreements with farmers, veterinarians can also receive these herd health reports for their clients to enable them to support herd management and provide effective consultation services. To this end, a veterinary version of the online herd management program (RDV4Vet, https://www.zar.at/Service/RDV-Portal/ RDV4Vet.html) is available.

Definition of Animal Health Benchmarks. Table 1 gives an overview of the animal health benchmarks that are available in the annual herd health reports. Because many parameters are complex, the use of several benchmarks is important.

Fertility. Several fertility parameters were of particular interest: interval from calving to first service (d), nonreturn rate at $90 \mathrm{~d}$, calving interval, and fertility diagnoses.

Udder Health. Udder health is described by the mean SCC and as the proportion of cows with SCC greater than 200,000 cells/mL, which often indicates underlying subclinical mastitis in dairy herds. Additional information, such as the frequency of udder diagnosis reporting, provides the opportunity to define management measures in a targeted manner.
Metabolic Health. To detect possible energy deficiencies of the cows in the herd, the proportion of animals with a fat:protein ratio $>1.5$ within the first $100 \mathrm{~d}$ after calving is a particularly valuable piece of information. Heuer et al. (1999) reported that cows with a fat:protein ratio $>1.5$ had higher risks for ketosis, displaced abomasum, ovarian cyst, lameness, and mastitis. Information on the frequency of metabolic diagnosis (milk fever, ketosis, and others) reporting allows more detailed analyses.

\section{Statistical Analysis}

All analyses were based on the annual herd health reports and are, therefore, taken from annual herd mean information and not from individual cow data. Annual herd health reports from all farms participating in the health monitoring system were considered, and analyses were conducted across breeds. A separate analysis for each breed was not possible, as many herds have more than one breed or crossbred cows. The main cattle breed in Austria is Fleckvieh (75.3\%), followed by Holstein (7.1\%) and Brown Swiss (6.4\%; ZAR, 2018). For diagnosis data, only data from validated farms were used. Criteria for validation were continuous data recording and the definition of a valid observation period, the incidence rate per farm, and the coding of the diagnoses, as previously described in detail by EggerDanner et al. (2013).

Farm-specific factors such as climate, altitude, soil quality, feeding (e.g., grass silage, maize silage, proportion of concentrate feeding, grazing), housing system, and other factors (e.g., organic or conventional farming) should be considered for benchmarking. Because a detailed description of the herd environment was not availabe, the present study compared herds by herd size and herd mean milk production.

All statistics were calculated using SAS software (SAS Institute Inc., Cary, NC). Arithmetric means, medians, and percentiles were calculated for animal health benchmarks based on the annual herd health reports. Farms were divided according to their herd size into 4 groups: $\leq 20$ cows, $>20$ to 40 cows, $>40$ to 60 cows, and $>60$ cows. Additionally farms were grouped according to their herd mean milk production as follows: $\leq 6,000 \mathrm{~kg},>6,000$ to $8,000 \mathrm{~kg},>8,000$ to $10,000 \mathrm{~kg}$, and $>10,000 \mathrm{~kg}$. A Kruskal-Wallis test was used to determine whether significant differences existed between the groups (Kruskal and Wallis, 1952). For multiple comparison, the Dwass, Steel, Critchlow-Fligner multiple comparison procedure was applied if the $P$-value was lower than 0.05 for the global null hypothesis. 
Egger-Danner et al.: DAIRY INDUSTRY TODAY

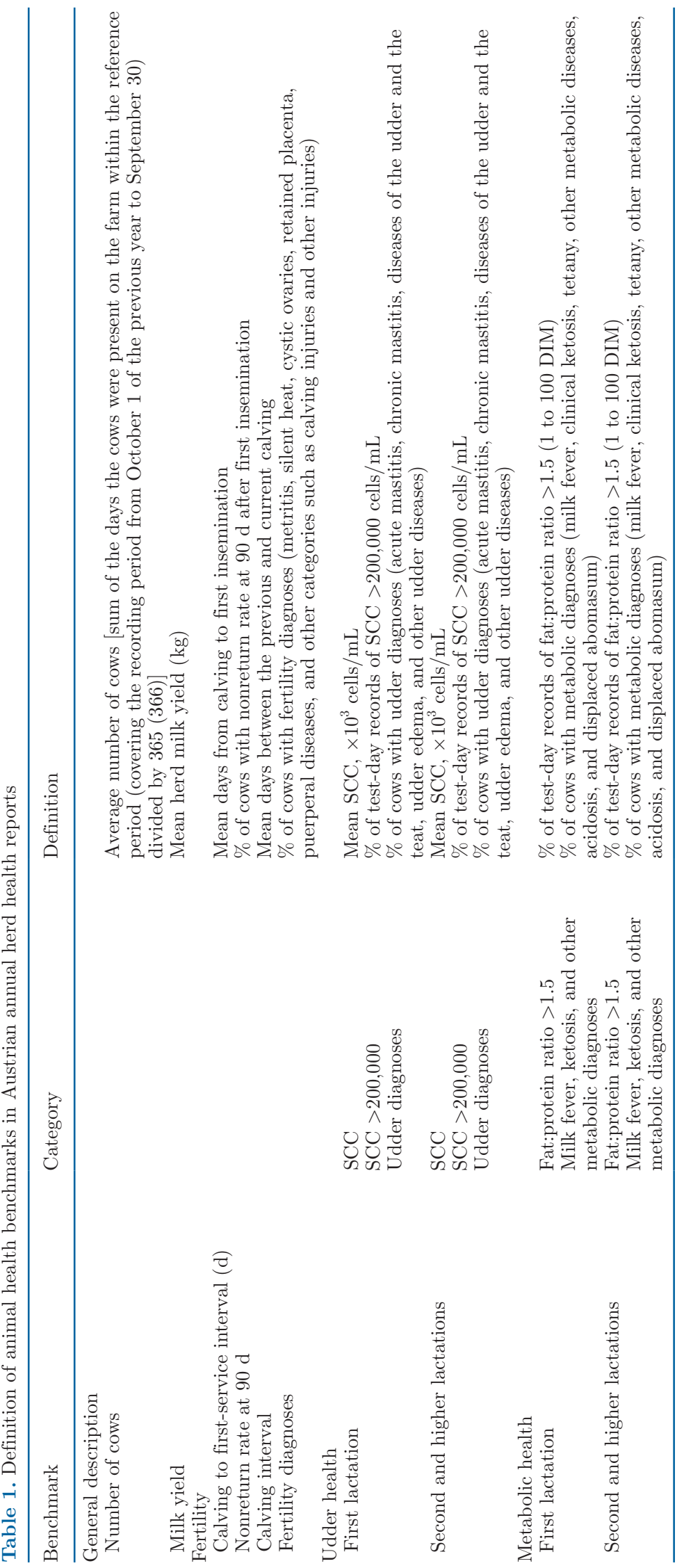




\section{RESULTS AND DISCUSSION}

\section{Development of Health Parameters}

Table 2 gives an overview of the development of the various animal health benchmarks from 2008 to 2017. Herd size and herd mean milk production increased slighlty, whereas fertility and health parameters remained almost unchanged, with the exception of SCC. A slight reduction in the herd mean SCC in first-lactation cows (from 124,000 in 2007 to 105,000 in 2017) and cows in their second lactation or higher (from 219,000 in 2007 to 186,000 in 2017) was observed (Table 2). The median and 25th and 75th percentiles also fell slightly over this period (Table 3 ). The opposite would be expected because of the negative genetic correlation between SCC and milk yield (Fuerst-Waltl et al., 2016). However, various genetic evaluations have demonstrated that the inclusion of fertility and health traits in the breeding program has led to the stabilization or improvement of these low-heritability traits, despite the great breeding progress in milk production (Figure 2). Better herd management through benchmarking and monitoring programmes may also have led to a slight additional reduction in the herd mean SCC. Since 2005, farmers have been able to participate in a specific udder health program of the Animal Health Service (BMASGK, 2005). In 2011, the quality assurance program QS-Milk was introduced, which aims in particular at ensuring and improving milk quality. Cows with SCC over 400,000 cells $/ \mathrm{mL}$ in 3 consecutive tests were to be documented by the farmer, and specific measures had to be carried out (e.g., dry-off, regular California Mastitis Test, bacteriological examination). If the result of the bacteriological examination was positive, further measures had to be taken (e.g., treatment of the cow by a veterinarian or drying off or culling the cow).

\section{Health Parameters Between Dairy Farms}

Agriculture in Austria is dominated by small family farms, with a high proportion of part-time farmers. According to the Agricultural Structure Survey 2016, 90\% of all farms in Austria are family-run, with $36 \%$ run by full-time farmers and $54 \%$ run by part-time farmers. The remaining $10 \%$ were joint ventures or participations in legal entities. Full-time farmers had, on average, 20 dairy cows, whereas part-time farms had, on average, only 9 dairy cows (Statistik Austria, 2019).

As shown in Table 4, the average herd size of the farms receiving health reports in 2017 was 21 dairy cows with a herd mean milk production of $7,055 \mathrm{~kg}$. The 25th and 75th percentiles (i.e., the "best" and "worst" $25 \%$ ) of farms in 2017 for the various health parameters show large differences between farms. For benchmarking, mean values are given to dairy farmers, although several parameters are not normally distributed. For example, the herd mean SCC is given, as this value is relevant for payment from dairies. Geometric means or log tranformations are not used for payment and would also be difficult to work with.

The annual herd health data are accessible to the farmer via the online herd management program LKVHerdenmanager. For the different health parameters, target values are given in the LKV-Herdenmanager, which should be achieved. An example is given in Table 5 for udder health, where target values are given for each milk recording. Target values will be updated yearly and are reached by the best $10 \%$ of farms. Several key figures are computed and summarized to help the farmer objectively monitor important risk factors in the lives of dairy cows (Baumgartner et al., 2018). These key figures show the proportion of cows with healthy udders in the herd, the new infection rate during lactation, chronically ill cows with poor prognoses, the new infection rate and the cure rate during dry period, as well as the rate of heifer mastitis in the herd.

For correct interpretation of the situation on farm, several parameters should always be considered together. Statements should not be made on individual values, as many parameters are multifactorial. Having low frequencies with respect to fertility disorders does not mean that all the cows are healthy and have a short calving interval, as shown in Figure 3a. It could also be that cows that do not breed because of untreated cystic ovaries have extended calving intervals or are even culled and removed from the herd. The same is observed for the trait complex udder health (Figure 3b). A low frequency of udder diagnoses does not prove that cows are healthy. The use of additional paramters such as SCC gives deeper insight into the udder health situation. The reason for lower frequencies in diagnoses can be related to the management of the farmer.

\section{Cow Herd Size and Animal Health}

It is important to note that, given the family-farm structure of Austrian dairy farms, the largest herds in the current study were classed as herds with $>60$ dairy cows. As shown in Figure 4, herd mean milk production increases significantly with herd size, as confirmed by the Kruskal-Wallis test. Boxplots of herd mean values for fertility and health parameters with respect to herd size are shown in Figure 5. The Kruskal-Wallis test determined that significant differences exist in all fertility and health parameters according to herd size, except for fertility diagnoses. The subsequently applied Dwass, 
Egger-Danner et al.: DAIRY INDUSTRY TODAY

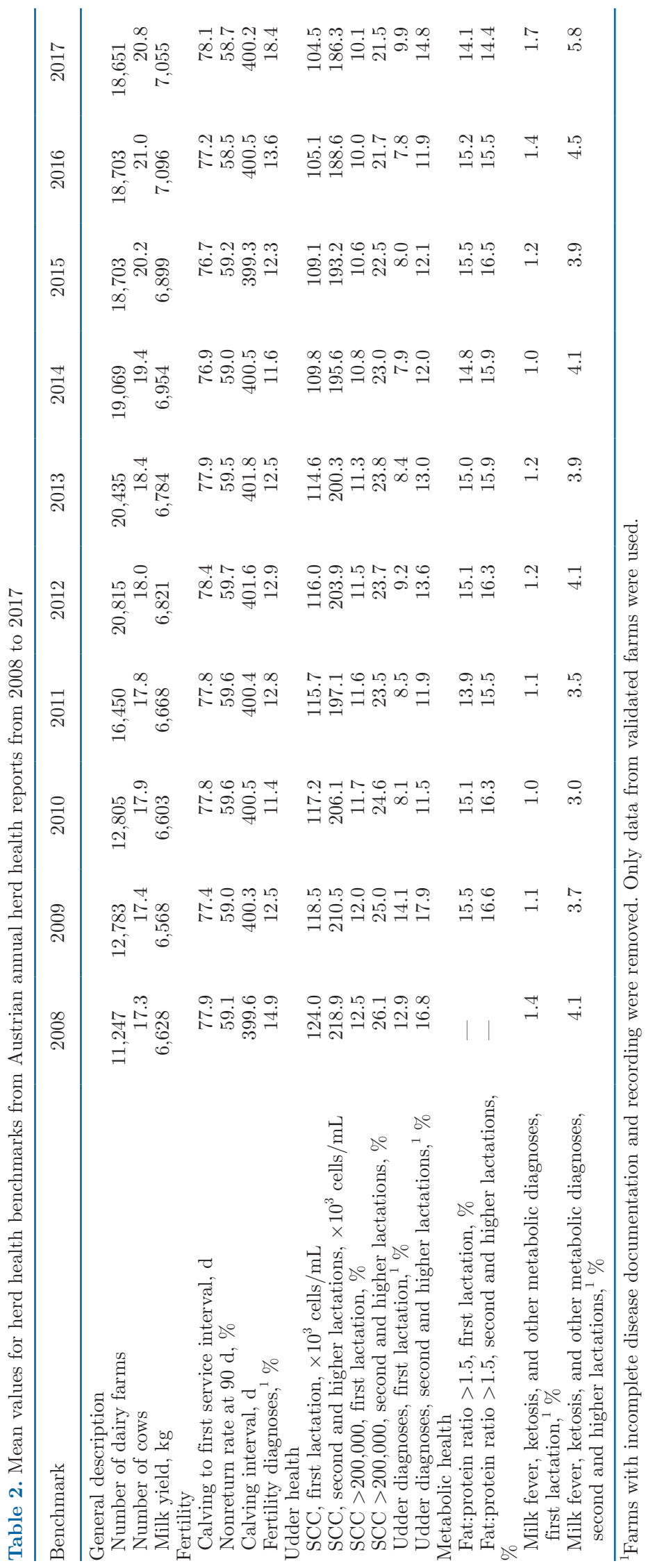


Table 3. Mean, SD, median, and 25th and 75th percentiles for SCC from 2008 to 2017 across all farms receiving the annual herd health reports

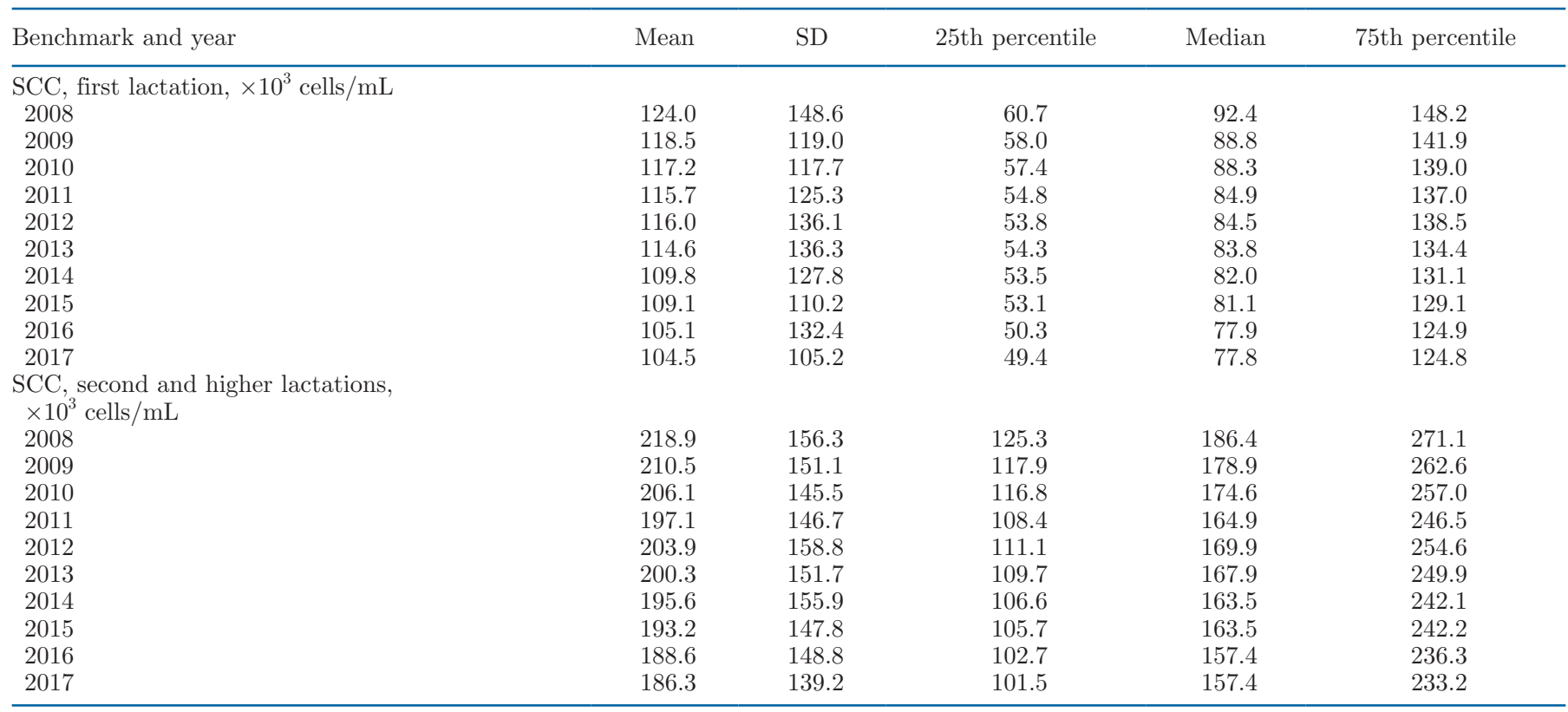

Steel, Critchlow-Fligner multiple comparison procedure showed that the smallest farms $(\leq 20$ cows $)$ differ in many parameters from larger farms $(>20$ cows $)$. The results concerning fertility demonstrated a significant difference between the smallest farms ( $\leq 20$ cows) and the larger herds. Larger farms tended to have a shorter interval from calving to first service, a lower nonreturn rate at $90 \mathrm{~d}$, and a shorter calving interval. Hardly any difference was noted with respect to the different fertility parameters between the herd size groups larger than 20 cows. The mean SCC and proportion of test-days with SCC over 200,000 cells/mL increased significantly

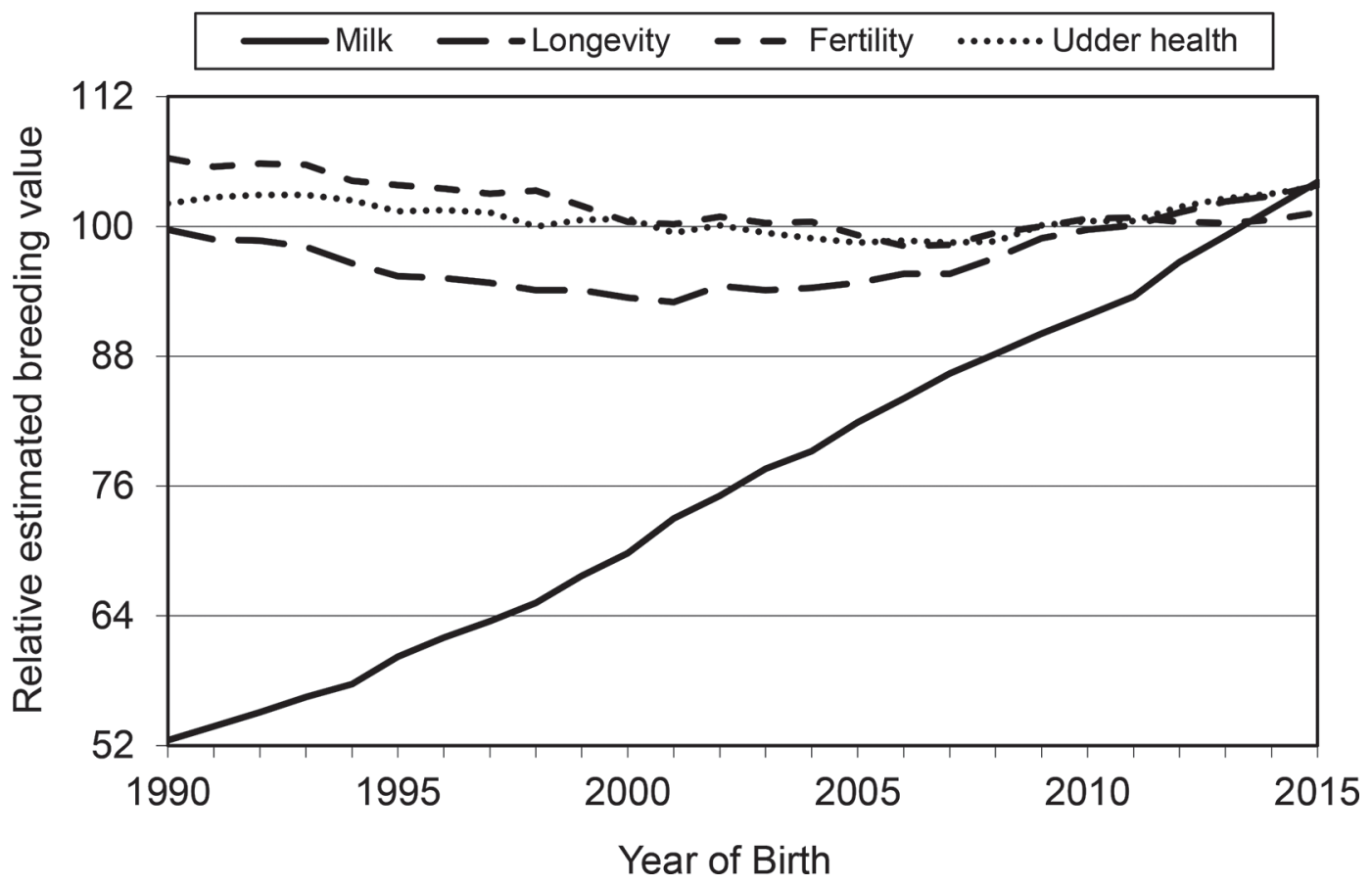

Figure 2. Development of genetic trends for Austrian Fleckvieh from 1990 to 2015 (ZuchtData, 2018). 
Table 4. Mean, SD, median, and 25th and 75th percentiles for fertility, udder health, and metabolic health across all farms receiving the annual herd health reports in 2017 (in total 18,651 farms; 7,804 farms with complete disease documentation and recording)

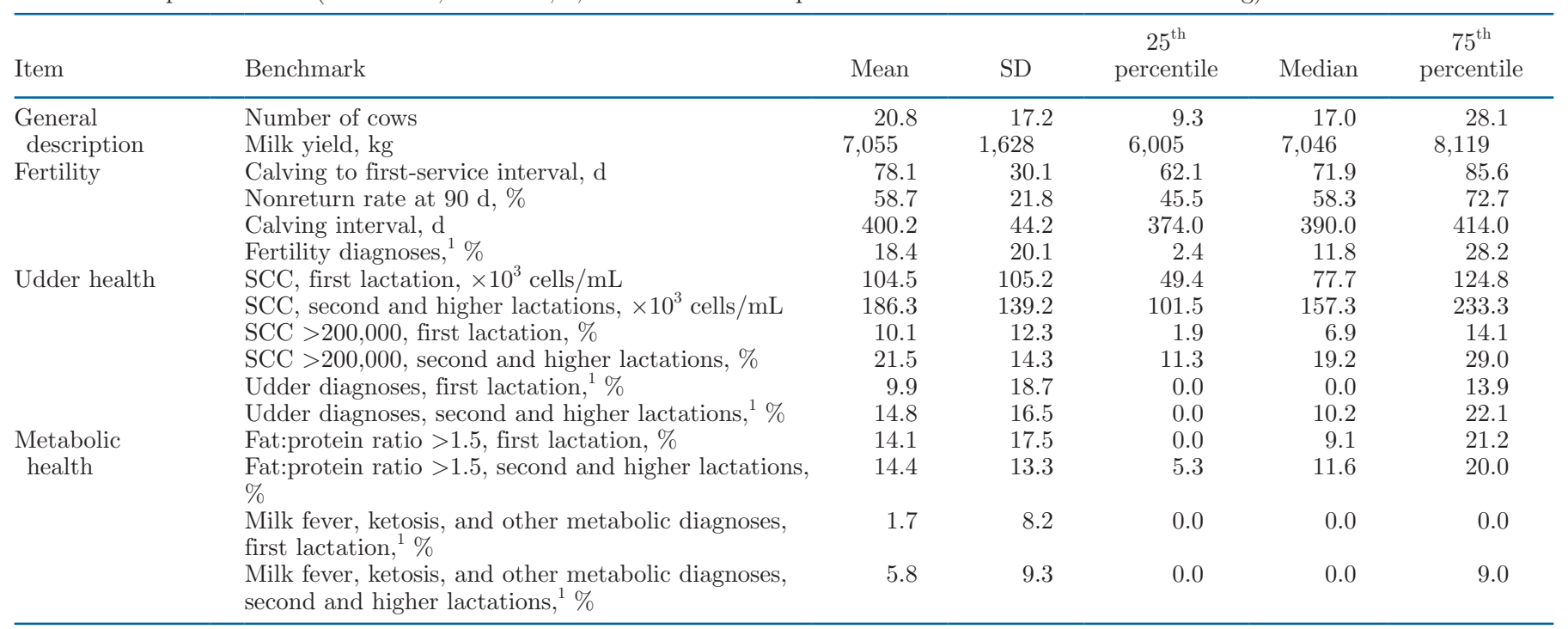

${ }^{1}$ Farms with incomplete disease documentation and recording were removed. Only data from validated farms were used.

with herd size, whereas differences in the proportion of cows with udder diagnoses were small between farms of different sizes. On larger farms (>20 cows) a higher percentage of test-days with a fat:protein ratio over 1.5 in the first lacation and a higher frequency of metablic disorders, particularly in the second and higher lactations, were observed. A reason for the better health status of the smaller farms, in regard to metabolic health, might be the fact that the mean milk yield of smaller farms is lower (Figure 4). Because even the largest herd sizes in Austria are very small on a global scale, comparison with results from other countries is difficult. In the study of Berge and Vertenten (2014), the minimum herd size for enrollment was set at 60 cows.
They reported that larger herd size was associated with a decreased risk of ketosis. Farms that fed partial mixed rations had 1.5 times higher odds of ketosis than those that fed TMR. Robbins et al. (2016) reviewed more than 150 publications that examined the relationship between mostly dairy cattle farm size and at least 1 animal welfare indicator, including disease incidence. They found little evidence of any simple relationship, negative or positive, between farm size and incidence of lameness, mastitis, and other diseases. The results of the Robbins review suggested that larger farms provide some opportunities to improve animal welfare, as larger farms require more specialized and professional management of animal health.

Table 5. Target values for udder health that are attained by the best $10 \%$ of farms (target values updated yearly)

Description

Target value

SCC at current milk recording

Proportion of cows with SCC $\leq 100,000$ cells $/ \mathrm{mL}$

Proportion of cows with SCC $>100,000$ cells $/ \mathrm{mL}$

$<10.7$

Proportion of cows with SCC $>200,000$ cells $/ \mathrm{mL}$

Proportion of cows with SCC $>400,000$ cells $/ \mathrm{mL}$

$<0.7$

Chronic mastitis

Proportion of cows with $\mathrm{SCC}>700,000$ cells $/ \mathrm{mL}$ at the last 3 milk recordings

$<0.0$

Heifer mastitis

Proportion of first-lactation cows with SCC $>100,000$ cells $/ \mathrm{mL}$ at the first milk recording after calving

$<13.6$

Dry cow new infection rate

Proportion of cows with SCC $>100,000$ cells $/ \mathrm{mL}$ at the first milk recroding after calving

and $\leq 100,000$ cells/mL at drying off

Dry cow cure rate

Proportion of cows with SCC $\leq 100,000$ cells $/ \mathrm{mL}$ at the first milk recroding after calving and $>100,000$ cells $/ \mathrm{mL}$ at drying off 


\section{Herd Mean Milk Production and Animal Health}

Boxplots of herd mean values for fertility and health parameters with respect to milk production are shown in Figure 6. The Kruskal-Wallis test determined that significant differences exist for all the fertility and health parameters according to herd mean milk production. The subsequently applied Dwass, Steel, Critchlow-

a)

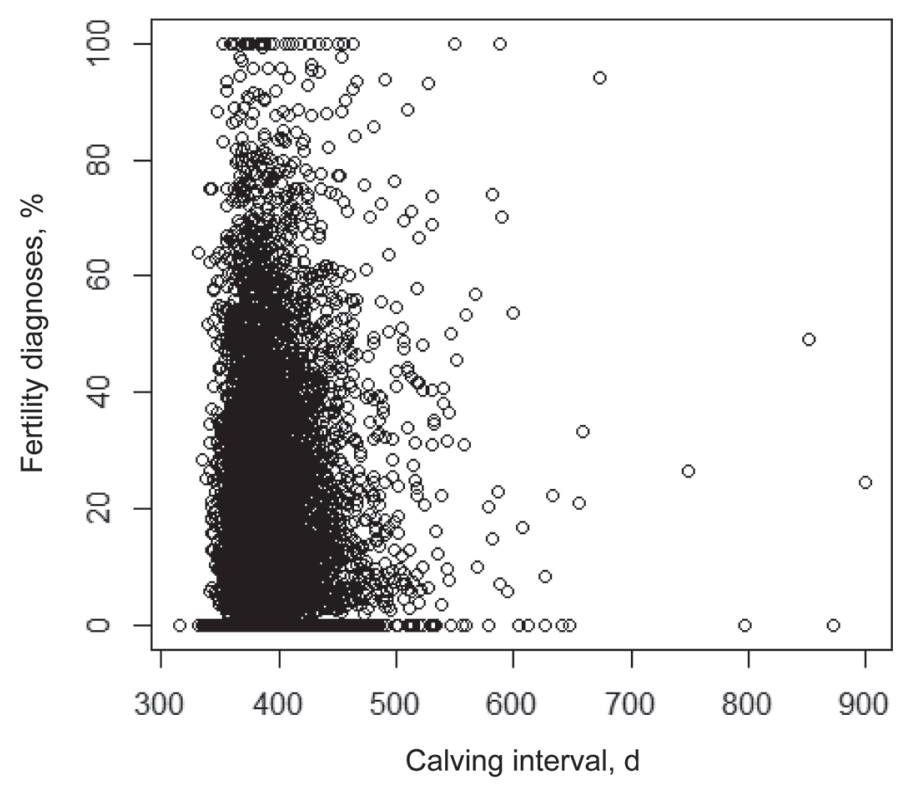

b)

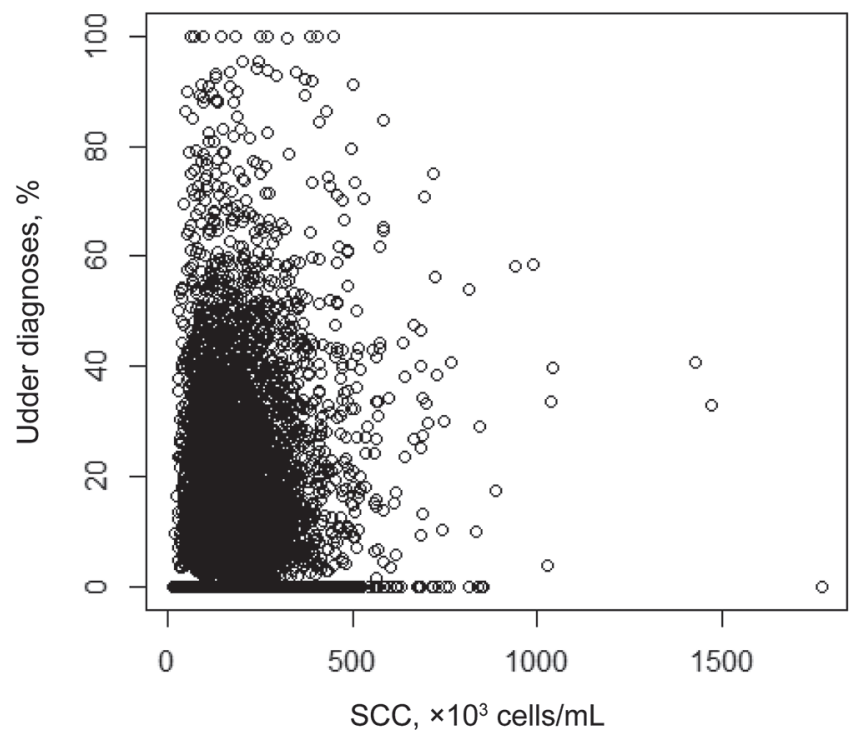

Figure 3. Association between (a) herd mean calving interval and fertility diagnoses, and (b) herd mean SCC and udder diagnoses in second and higher lactations.
Fligner multiple comparison procedure showed that high-yielding herds $(>8,000 \mathrm{~kg})$ had a shorter interval from calving to first service, a lower nonreturn rate at $90 \mathrm{~d}$, and more fertility diagnoses reported. The calving interval was shorter compared with herds with lower milk production. The results also demonstrated that, as the herd mean milk production increases, the mean SCC in second and higher lactations was slightly lower, as was the proportion of individual records with SCC over 200,000 cells/mL, whereas frequencies of mastitis diagnoses increased. This may be due to the fact that farms with higher milk yields generally have a more professional management level and that these farmers are relatively proactive in terms of consulting a veterinarian earlier than those with lower milk yields. The result is that the SCC is lower, and, with respect to fertility, the calving interval is shorter. The proportion of test-day records with a fat:protein ratio above 1.5 was not significantly different between the farms with the lowest and highest milk production. Farms with higher mean milk yield report more metabolic disorders. The results of the present study are in agreement with an earlier study by Windig et al. (2005). They found that in high-intensity herds, SCC levels were lower, and first insemination after calving took place earlier but with lower success than in lower-producing herds.

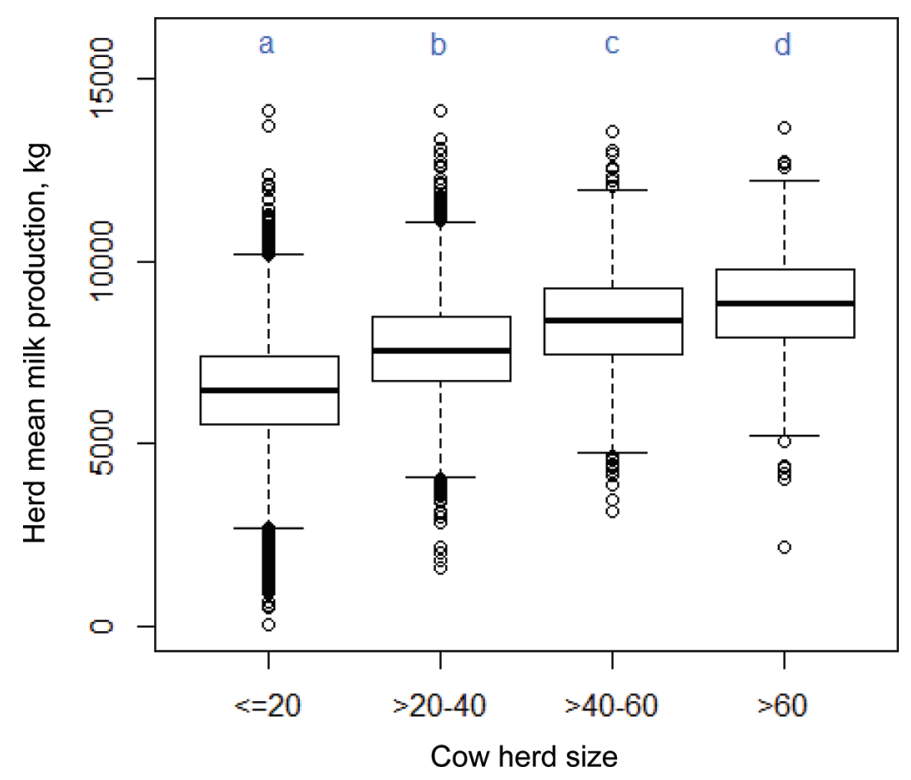

Figure 4. Herd mean milk production according to cow herd size in 2017. Values with different letters (a-d) are significantly different $(P$ $<0.05$ ), as determined by the Dwass, Steel, Critchlow-Fligner multiple comparison procedure. The plots show the median (line within box), 25 th and 75 th percentiles (box), 10th and 90th percentiles (whiskers), and outliers (dots). 

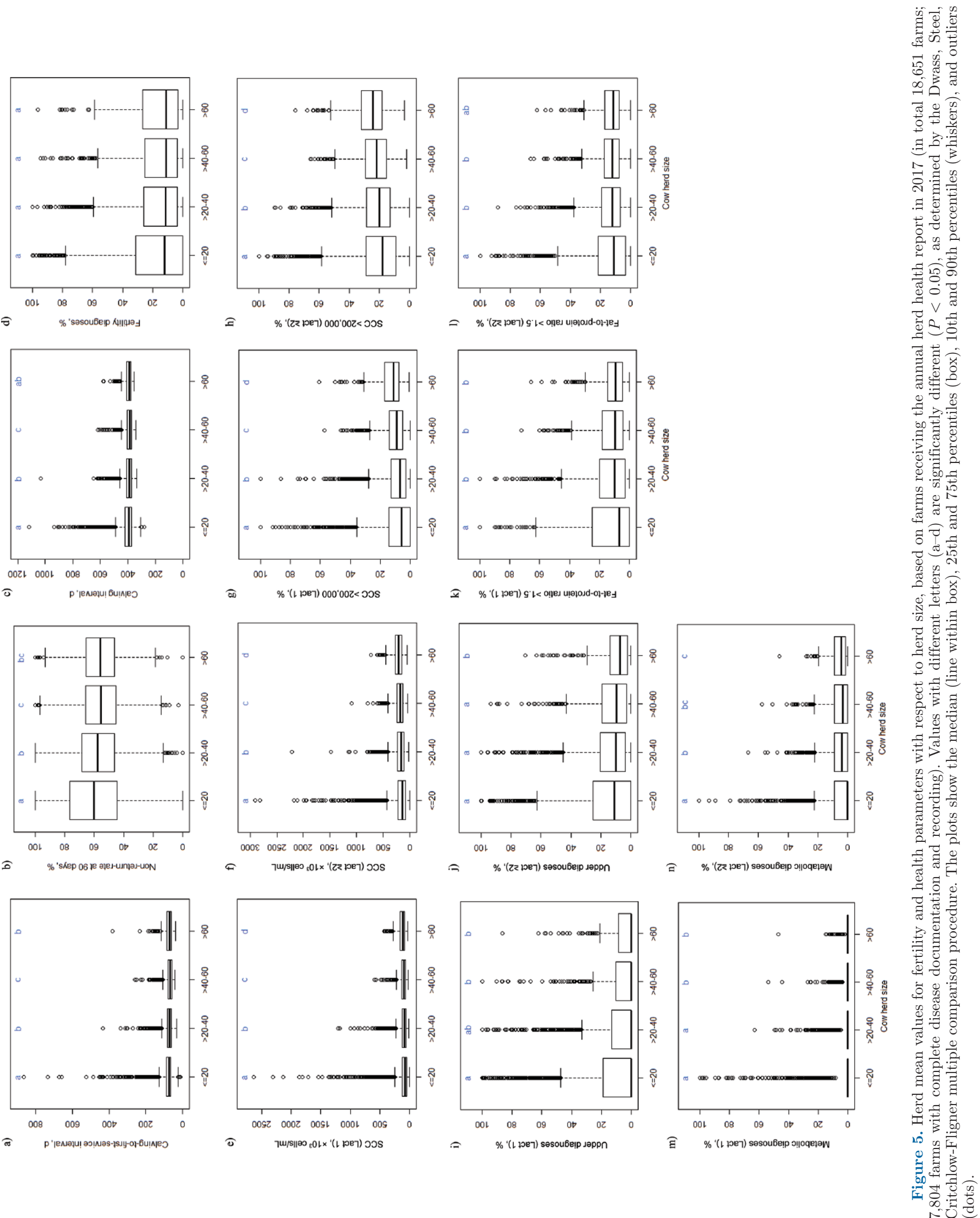

p'|enezul 6uinges
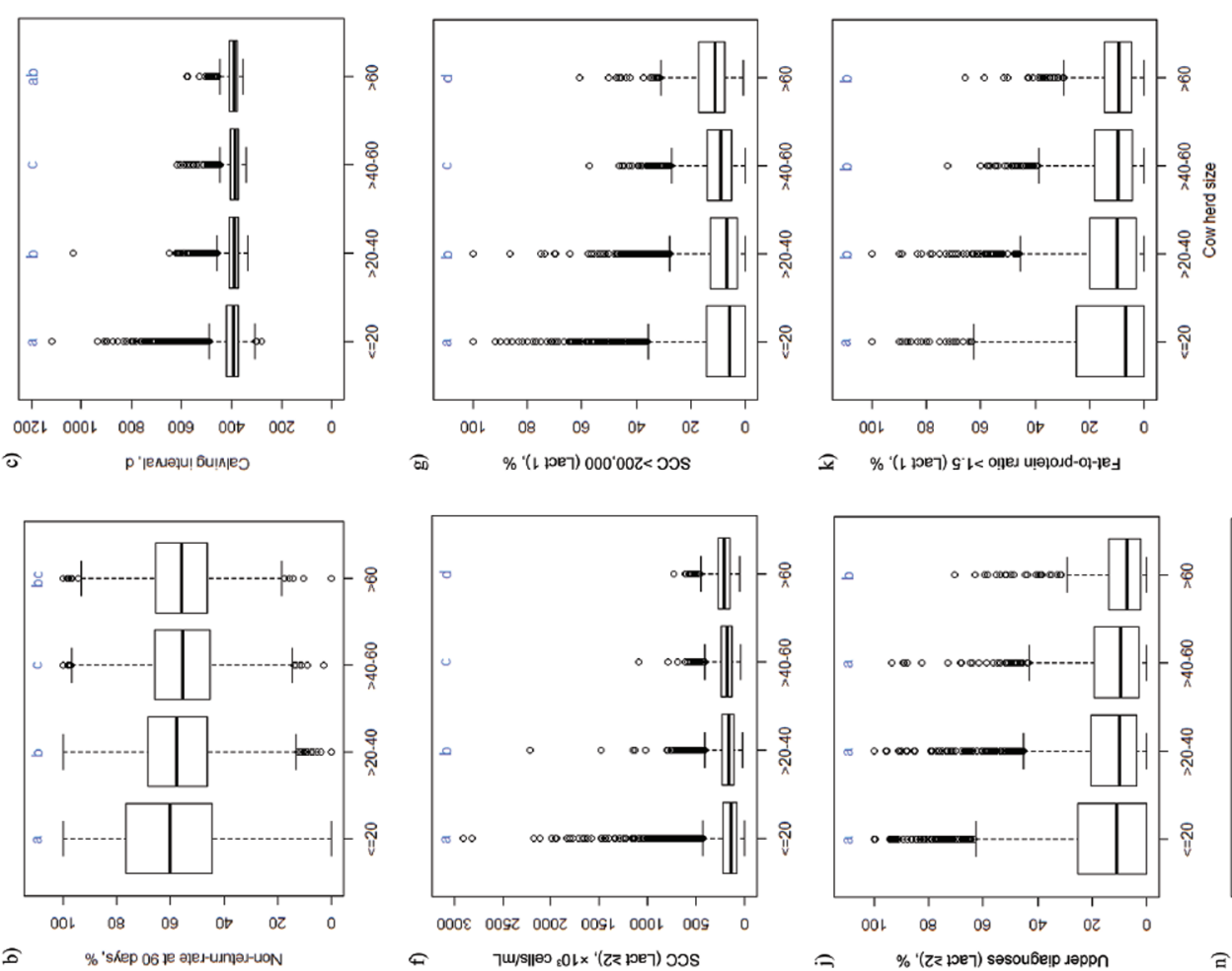

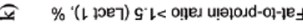
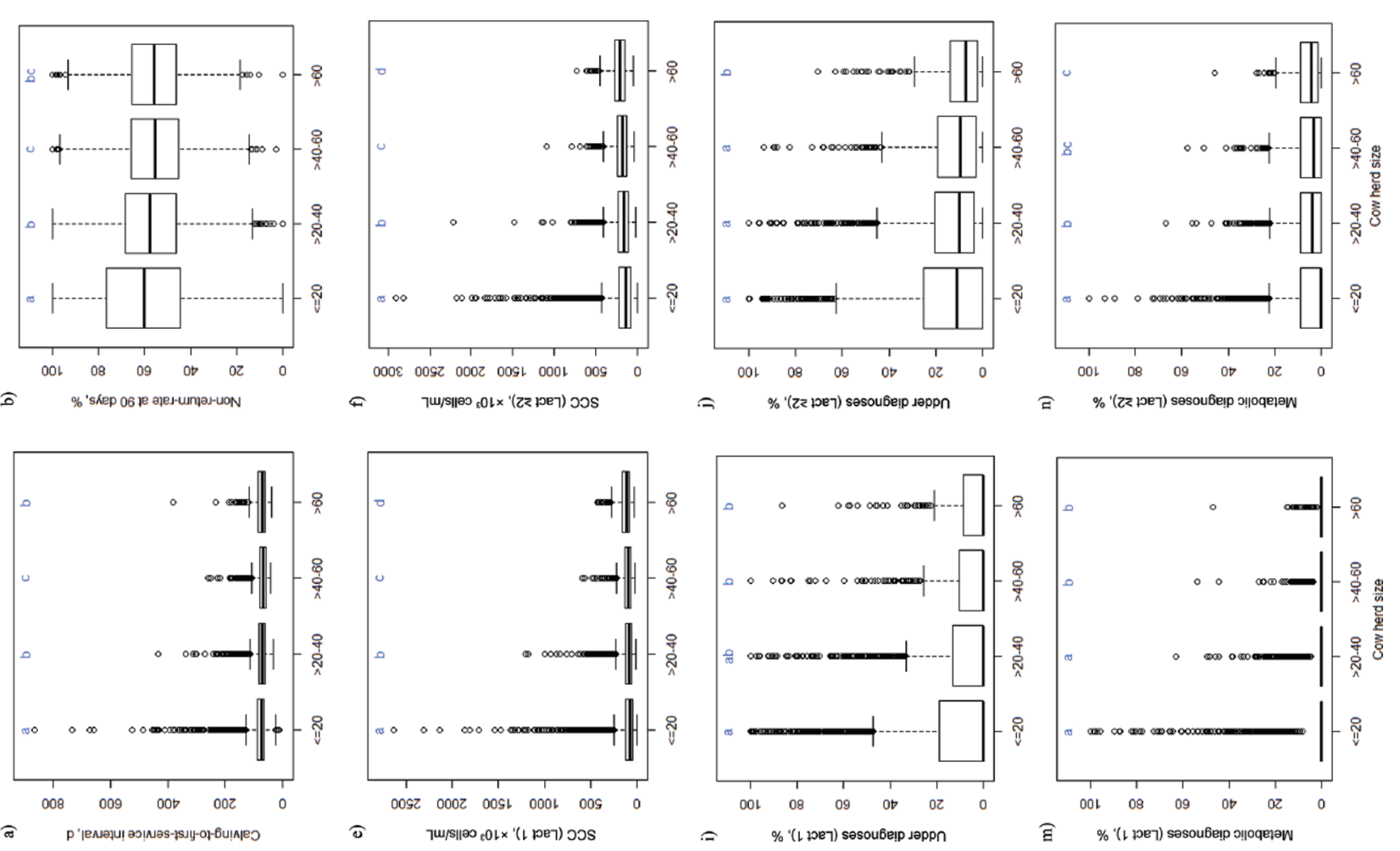

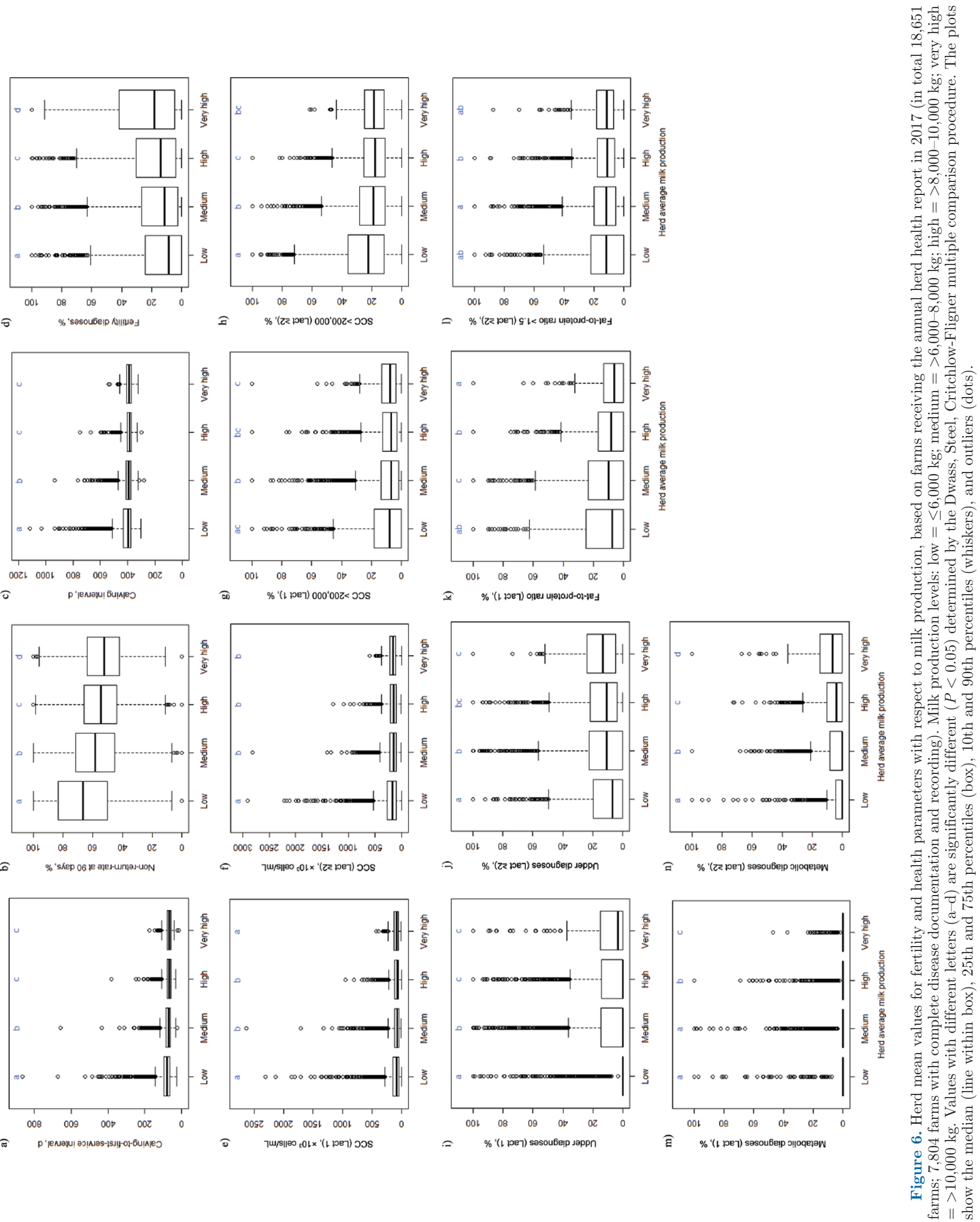

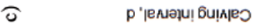

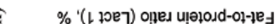
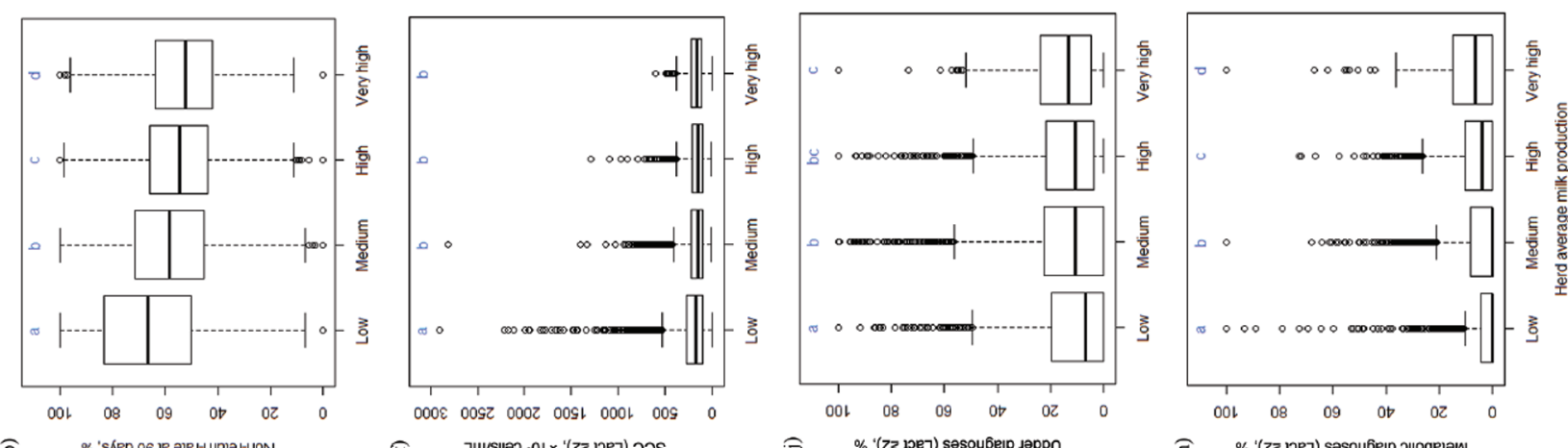

$\hat{0}$

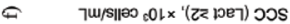

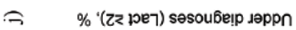

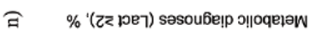
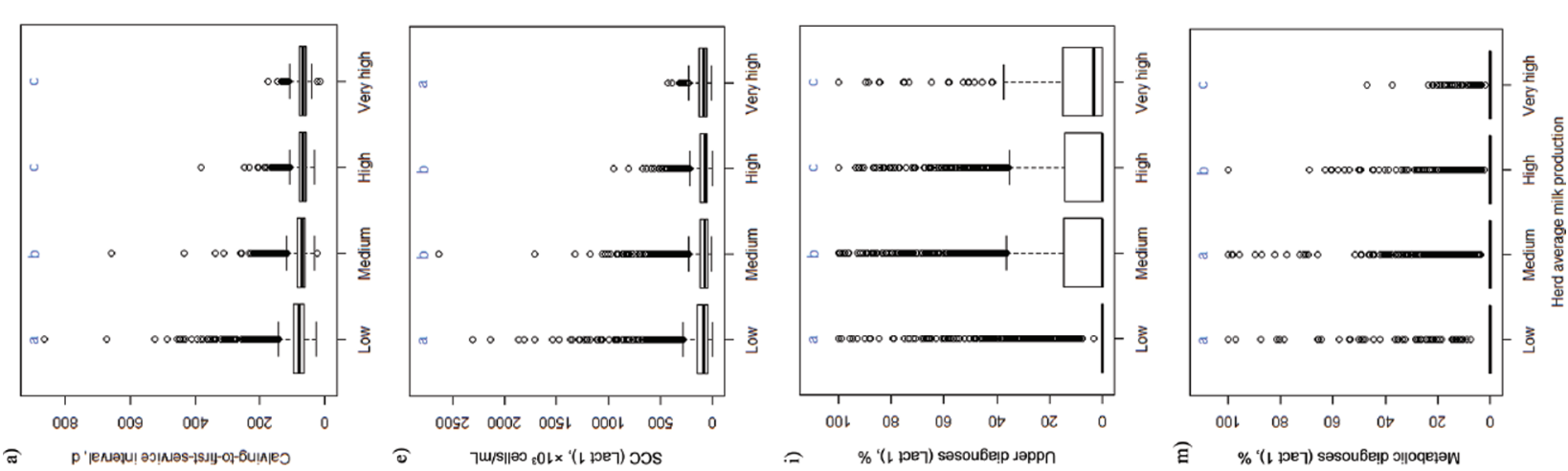


\section{Final Remarks}

The basis for meaningful comparison across farms is complete recording and documentation of the various parameters on farm. Particular caution should be taken when interpreting diagnostic data. For example, previous Austrian studies have determined that the frequency of specific diagnosis reporting is higher from farms with electronic data transmission, as diagnosis data from electronic data collection are more complete than paper data (Egger-Danner et al., 2013). Veterinarians working electronically document everything more accurately. If a farmer, consultant, or veterinarian wants to compare disease frequencies from a variety of farmers, then this factor must be taken into consideration. In the present study, only diagnosis data from validated farms were used for the calculation of benchmarks.

The frequency of diagnoses is also influenced by the health management of the farm. Some farmers are very active and consult the veterinarian at an early stage. This factor can also explain why high-yielding farms, which have higher frequencies of fertility and udder diagnoses, have, on average, lower calving intervals and lower mean SCC in second and higher lactations.

Fertility and health benchmarks are also used to monitor the Austrian dairy cattle population to detect long-term negative trends and as an early warning system. Information on health status is used for the development of training programs, the identification of target groups, and the improvement of animal health policies. A summarized analysis of performance and health indicators for the Austrian dairy cattle population is provided annually to the Animal Health Service and the Federal Ministry of Labour, Social Affairs, Health and Consumer Protection (responsible for government veterinary services).

The animal health reports are continuously being developed and new parameters integrated, such as bacteriological milk samples (Schabauer et al., 2018; Suntinger et al., 2018) and antimicrobial agents (Firth et al., 2017). Current Austrian projects aim to establish new animal health benchmarks, such as claw health (https://www.zar.at/Projekte/Klauen-Q-Wohl.html) and subclinical ketosis (https://www.zar.at/Projekte/ FoKUHs.html; https://d4dairy.com/de/).

\section{CONCLUSIONS}

Benchmarking assists dairy farmers in monitoring animal health and welfare and identifying potential targets for improvement by comparison to other farms with similar management practices. Using data from the Austrian routine recording system, farmers and their veterinarians (with the consent of the farmer) can compare farm parameters with detailed data available from their region and ensure more efficient herd management. Data from Austrian reporting demonstrated that large variation exists between farms. The results show that, based on parameters of milk yield and herd size for the range of farms within this study, it cannot be concluded that these circumstances automatically lead to poor animal health. Management practices can compensate, to a high extent, for the negative genetic correlation between milk yield and reproduction and health. An active health management program might result in higher incidence rates based on diagnoses that might be economically superior, if, for example, the calving interval can be shortened or SCC can be reduced. These results show that single parameters are not sufficient to evaluate complex parameters, such as fertility, udder health, or metabolic health. Therefore it is adviseable to combine several different benchmarks for monitoring health, as well as for deciding on strategies to improve overall herd health management. Providing benchmarks on the performance of other comparable farms gives farmers and herd managers ideas about their potential for improvement.

\section{ACKNOWLEDGMENTS}

We thank the farmers, veterinarians, and routine performance organizations (LKV Austria, Vienna, Austria) for providing the data. This study is supported by the Electronic Herd Book project, funded by the Federal Ministry of Labour, Social Affairs, Health and Consumer Protection (Vienna) and the COMET Projects ADDA - Advancement of Dairying in Austria and D4Dairy-Digitalisation, Data Integration, Detection, Decision Support in Dairying in Austria (Vienna). These projects are supported by BMK (Federal Ministry Republic of Austria Climate Action, Environment, Energy, Mobility, Innovation and Technology), BMDW (Federal Ministry Republic of Austria Digital and Economic Affairs, Vienna), the province of Lower Austria, and the city of Vienna in the framework of COMETCompetence Centers for Excellent Technologies. The COMET program is handled by the FFG (Austrian Research Promotion Agency, Vienna). The authors acknowledge the support of Clair Firth (University of Veterinary Medicine, Vienna) and Elisabeth Hehenberger (Veterinary practice HöllerVet, Wallsee). The authors do not have any conflicts of interest.

\section{REFERENCES}

Barkema, H. W., M. A. G. von Keyserlingk, J. P. Kastelic, T. J. G. M. Lam, C. Luby, J.-P. Roy, S. J. LeBlanc, G. P. Keefe, and D. 
F. Kelton. 2015. Invited review: Changes in the dairy industry affecting dairy cattle health and welfare. J. Dairy Sci. 98:7426-7445. https://doi.org/10.3168/jds.2015-9377.

Baumgartner, C., B. Behr, and S. Hachenberg. 2018. Strategic udder health monitoring and benchmarking based on national SCC data in Germany. International Committee for Animal Recording. J. Bryant, M. Burke, R. Cook, B. Harris, C. Mosconi, and B. Wickham, ed. ICAR Technical Series no. 23. Accessed Dec. 16, 2019. https://www.icar.org/wp-content/uploads/2018/07/ICAR -Technical-Series-23-Auckland-2018-Proceedings.pdf.

Berge, A. C., and G. Vertenten. 2014. A field study to determine the prevalence, dairy herd management systems, and fresh cow clinical conditions associated with ketosis in western European dairy herds. J. Dairy Sci. 97:2145-2154. https://doi.org/10.3168/jds .2013-7163.

BMASGK. 2005. Udder health programme of the Animal Health Service (Modul "Eutergesundheit" im Rahmen des "Betreuungspaketes Rind"). Accessed Dec. 16, 2019. https://www .verbrauchergesundheit.gv.at/tiere/recht/kundmachungen/ 2 _Anlage_Modul_Eutergesundheit_im_Rahmen_des _Betreuungspaket.pdf?63xzkv.

Colditz, I., D. Ferguson, T. Collins, L. Matthews, and P. Hemsworth. 2014. A prototype tool to enable farmers to measure and improve the welfare performance of the farm animal enterprise: The unified field index. Animals 4:446-462.

Egger-Danner, C., B. Fuerst-Waltl, W. Obritzhauser, C. Fuerst, H. Schwarzenbacher, B. Grassauer, M. Mayerhofer, and A. Koeck. 2012. Recording of direct health traits in Austria-Experience report with emphasis on aspects of availability for breeding purposes. J. Dairy Sci. 95:2765-2777. https://doi.org/10.3168/jds.2011 -4876 .

Egger-Danner, C., W. Obritzhauser, C. Fuerst, B. Grassauer, K. Zottl, K. Fuchs, and B. Fuerst-Waltl. 2013. Aspects of validation and data quality based on veterinary diagnoses. International Committee for Animal Recording. C. Egger-Danner, O. K. Hansen, K. Stock, J. E. Pryce, J. Cole, N. Gengler, and B. Heringstad, ed. ICAR Technical Series No. 17. Accessed Dec. 16, 2019. http:// www.icar.org/Documents/technical_series/tec_series_17_Aarhus .pdf.

Firth, C. L., A. Käsbohrer, C. Schleicher, K. Fuchs, C. Egger-Danner, M. Mayerhofer, H. Schobersberger, J. Köfer, and W. Obritzhauser. 2017. Antimicrobial consumption on Austrian dairy farms: An observational study of udder disease treatments based on veterinary medication records. PeerJ 5:e4072. https://doi.org/10.7717/peerj .4072 .

Fuerst-Waltl, B., C. Fuerst, W. Obritzhauser, and C. Egger-Danner. 2016. Sustainable breeding objectives and possible selection response: Finding the balance between economics and breeders references. J. Dairy Sci. 99:9796-9809. https://doi.org/10.3168/jds 2016-11095.

Heuer, C., Y. H. Schukken, and P. Dobbelaar. 1999. Postpartum body condition score and results from the first test day milk as predictors of disease, fertility, yield, and culling in commercial dairy herds. J. Dairy Sci. 82:295-304. https://doi.org/10.3168/jds.S0022 -0302(99)75236-7.

Hultgren, J. 2017. Key issues in the welfare of dairy cattle. Accessed Dec. 16, 2019. https://pub.epsilon.slu.se/14532/127/hultgren_j 171206.pdf.

ICAR (International Committee for Animal Recording). 2018. Accessed Dec. 16, 2019. http://www.icar.org/survey/pages/tables .php.

Kruskal, W., and W. Wallis. 1952. Use of ranks in one-criterion variance analysis. J. Am. Stat. Assoc. 47:583-621. https://doi.org/10 $.1080 / 01621459.1952 .10483441$.
Krystallis, A., M. D. de Barcellos, J. O. Kügler, W. Verbeke, and K. G. Grunert. 2009. Attitudes of European citizens towards pig production systems. Livest. Sci. 126:46-56. https://doi.org/10.1016/ j.livsci.2009.05.016.

Lassen, J., P. Sandøe, and B. Forkman. 2006. Happy pigs are dirty! Conflicting perspectives on animal welfare. Livest. Sci. 103:221230. https://doi.org/10.1016/j.livsci.2006.05.008.

Lusk, J. L., F. B. Norwood, and R. W. Pricket. 2007. Consumer preferences for farm animal welfare: Results of a nationwide telephone survey. Working paper. Dept. Agric. Econ., Oklahoma State Univ., Stillwater.

Robbins, J. A., M. A. G. von Keyserlingk, D. Fraser, and D. M. Weary. 2016. Invited review: Farm size and animal welfare. J. Anim. Sci. 94:5439-5455. https://doi.org/10.2527/jas.2016-0805.

Schabauer, A., B. Pinior, C. M. Gruber, C. L. Firth, A. Käsbohrer, M. Wagner, K. Rychli, and W. Obritzhauser. 2018. The relationship between clinical signs and microbiological species, spa type, and antimicrobial resistance in bovine mastitis cases in Austria. Vet. Microbiol. 227:52-60. https://doi.org/10.1016/j.vetmic.2018 .10 .024 .

Statistik Austria. 2019. Agrarstrukturerhebung 2016. Accessed Dec. 16, 2019. https://www.statistik.at/web_de/statistiken/wirtschaft/ land_und_forstwirtschaft/index.html.

Suntinger, M., W. Obritzhauser, B. Fuerst-Waltl, C. Firth, M. Mayerhofer, and C. Egger-Danner. 2018. From data integration to practical application: A pathogen-specific udder health management tool. Page 391 in Book of Abstracts of the 69th Annual Meeting of the European Federation of Animal Science No. 24. Wageningen Academic Publishers, Wageningen, the Netherlands.

Tonsor, G. T., N. Olynk, and C. Wolf. 2009. Consumer preferences for animal welfare attributes: The case of gestation crates. J. Agric. Appl. Econ. 41:713-730. https://doi.org/10.1017/ S1074070800003175.

von Keyserlingk, M. A., N. P. Martin, E. Kebreab, K. F. Knowlton, R. J. Grant, M. Stephenson, C. J. Sniffen, J. P. Harner III, A. D. Wright, and S. I. Smith. 2013. Invited review: Sustainability of the US dairy industry. J. Dairy Sci. 96:5405-5425. https://doi.org/10 $.3168 /$ jds.2012-6354.

von Keyserlingk, M. A. G., A. Barrientos, K. Ito, E. Galo, and D. M. Weary. 2012. Benchmarking cow comfort on North American freestall dairies: Lameness, leg injuries, lying time, facility design and management, for high-producing Holstein dairy cows. J. Dairy Sci. 95:7399-7408. https://doi.org/10.3168/jds.2012-5807.

Windig, J. J., M. P. L. Calus, and R. F. Veerkamp. 2005. Influence of herd environment on health and fertility and their relationship with milk production. J. Dairy Sci. 88:335-347. https://doi.org/10 .3168/jds.S0022-0302(05)72693-X.

ZAR. 2018. ZAR-Jahresbericht 2017. Accessed Dec. 16, 2019. https:// www.zar.at/Downloads/Jahresberichte/ZAR-Jahresberichte.html.

ZuchtData. 2018. ZuchtData Jahresbericht 2018. Accessed Dec. 16, 2019. https://zar.at/Downloads/Jahresberichte/ZuchtData -Jahresberichte.html.

\section{ORCIDS}

C. Egger-Danner $\odot$ https://orcid.org/0000-0002-8879-6845

A. Köck 우 https://orcid.org/0000-0002-1611-8017

B. Fuerst-Waltl @ https://orcid.org/0000-0002-4336-5830

W. Obritzhauser @ https://orcid.org/0000-0002-2041-5081 